Cilt/Volume: $18 \quad$ Sayl/Issue: 1 Mart/March 2020 ss./pp. 317-331

B. Reçber, Doi: http://dx.doi.org/10.11611/yead.687526

\title{
SOSYAL ÇALIŞMACILARIN SIĞINMACILARLA YAPTIKLARI ÇALIŞMALARDA ETİK DURUM: FRANSA ÖRNEĞİ
}

\section{Dr. Bircan REÇBER *}

\section{ÖZET}

Sosyal çalışmacılar görevlerini tâbi oldukları mevzuata göre yerine getirmektedirler. Bu tür görevlerin yerine getirilmesinde veya kendilerine tanınan yetkilerin kullanılmasında sosyal çalışmacılar, çeşitli nedenlerle mesleki ikilemler yaşamakla karşı karşıya kalabilmektedirler. Böyle bir durum Dünyanın her yerinde görülebilmekte veya tespit edilebilmektedir.

Kоnи kapsamında sosyal çalışmacılar, sığınma talebinde bulunanlara yönelik çalışma yürütürlerken, çeşitli otoritelerin veya kendilerinin üstünde olan amirlerinin istemleri karşısında problem yaşayabilmektedirler. Çünkü kimi durumlarda bu otoriteler veya amirler sığınmacılara ait gizlilik gibi hususları gerektiren kişisel bilgileri de isteyebilmektedirler. Çalışmada bu husus çeşitli örnek durumlarla açıklanmaya çalışılmıştr.

Çalışmada "sosyal çalışmacı" kavramı Fransa'da kullanılan şekliyle ele alınmıştır. Bu nedenle bu kavrama iliş̧kin Fransa'daki durum doğrultusunda konunun değerlendirmeye alındığını önemle vurgulamak gerekir. Çalışmanın bütünlüğ̈̈ içerisinde Fransa'daki sosyal çalışmacıların, sı̆̆ınma talebinde (siyasi, ekonomik vb.) bulunan kişilere iliş̧kin karşılaştıkları problemler tanıtılmış ve bu konuda olası çözüm metotlarının ne olduğu aktarılmaya çalışılmıştır.

Anahtar Kelimeler: : Sosyal Çalışmacılar, Sı̆̆ınmacılar, Etik Durum, Fransa Örneği.

JEL Kodlarl: Q3, Z0, Z1.

\section{ETHICAL SITUATION OF PRACTICES OF SOCIAL WORKERS WITH ASYLUM SEEKERS: THE CASE OF FRANCE}

\begin{abstract}
Social workers perform their duties in accordance with the legislation. In fulfilling their tasks, they may face situations that may be contrary to their professional principles for various reasons. Such situations can be observed anywhere in the world.
\end{abstract}

* Bursa Uludağ Üniversitesi, Devlet Konservatuvarı, Bursa/Türkiye, e-mail: recberb@uludag.edu.tr

\section{Makale Geçmiși/Article History}


Social workers may have problems while dealing with asylum seekers since various authorities may request personal information about asylum seekers. The study tries to explain these situations, giving examples.

The concept of "social worker" is handled as used in France in the study. Thus, it should be underlined that the subject is evaluated in line with the situation in France regarding this concept. The study elaborates the problems (political, economic, etc.) of asylums-seekers that social workers in France face and introduces the possible solution methods.

Keywords: Social Workers, Asylum Seekers, Ethical Situation, Case of France.

JEL Codes: Q3, ZO, Z1.

\section{GİRIŞ}

Sosyal hizmet mesleği Dünyanın birçok yerinde benimsenen ve uygulanan önemli bir alandır. Sosyal hizmetin geçmişi çok eski olmakla beraber, sosyal, ekonomik, kültürel vb. sorunların toplum açısından artmasıyla, bu meslek daha da önemli hale gelmiştir. Hatta gelişmiş olduğu iddia edilen veya genel anlamda kabul edilen özellikle batı Avrupalı toplumlarda sosyal hizmet mesleğine verilen önem ve yüklenilen anlam giderek artmaktadır.

Sosyal hizmet uzmanları, mesleki uygulamalar sırasında sı sık sorumlulukları ve değerleri arasında çatışmalar yaşayarak ikilemde kalmaktadırlar. Bütün mesleklerde olduğu gibi sosyal hizmet mesleğinde de etik değerler mesleki uygulamalardaki doğruyu ve yalnışı tanımlalayarak yaşanan/yaşanması olası olan ikilemlerin ortadan kalkmasına yardımcı olmaktadır. Mesleki kurallar olarak da tanımlanan etik kurallar, bir mesleğin güvencesi olarak mesleğin toplum tarafından güvenilir olmasını ve sürekliliğini sağlamaktadır. Sosyal hizmet mesleğinin etik değerleri aslında mesleğin temel ilkeleri ile de ilişkilidir. Bu ilkeler;

- Sosyal problemleri olan ve ihtiyaç içerisindeki kişilere yardım etmek (hizmet değeri);

- Sosyal adaletsizliklerle mücadele etmek (sosyal adalet);

- Her kişinin kendine özgü değer yargıları olduğuna ve bu nedenle saygı görmesi gerektiğine inanmak;

- İnsan ilişkilerinin önemini kabul etmek;

- Güvenilir ve ve dürüst bir biçimde davranmak;

- Mesleki yeterliklerini uygulama alanlarında göstermek ve mesleki uzmanlıklarını geliştirmek (yeterlik) olmak üzere altı grupta toplamak mümkün olabilmektedir (Reamer, 2006: 251-255).

Sosyal hizmet uzmanlarının, uygulamada ikilemler ve çelişkiler yaşadıkları anlar değerlerin kullanılmasına yönelik hedef ve önceliklerin belirlenmesi gerektiği anlar olmaktadır (Şahin Taşğın, 2019: 1024). Sosyal hizmet, alan olarak insan hakları ihlallerini önlemek üzere sosyal adaleti sağlamaya çalışmaktadır. Gökçesralan ve Gönen'nin aktarımına göre sosyal hizmet uzmanları sosyal adaletin 
Yönetim ve Ekonomi Araștırmalarl Dergisi / Journal of Management and Economics Research

Cilt/Volume: $18 \quad$ Sayl/Issue: 1 Mart/March 2020 ss./pp. 317-331

B. Reçber, Doi: http://dx.doi.org/10.11611/yead.687526

sağlanmasında sırasında gizlilik, doğru söyleme, kişinin kendi hayatı hakkında kendi kararını verme hakkı (self determinasyon), yasal düzenlemeler, meslektaş baskısı, sınırlı kaynakların dağıtımı, bireysel ve mesleki değerler olmak üzere yedi ana çatışma yaşamaktadırlar (Gökçesralan ve Gönen, 2011: 149$160)$.

İnsan onurunu ve değerini temel alan etik kavramı, sosyal hizmet uygulamalarında sosyal hizmet açısından da benimsenen veya önem atfedilen "insan olarak kişinin değerine ve onuruna saygl göstermek" ve "ihtiyaç içinde bulunan kişinin kendisi ile ilgili kararlarda karar verme hakkına sahip olmasına saygı göstermek" ilkeleriyle de sıkı ilişki içerisindedir. Sosyal hizmet mesleki uygulamaları, insanların ihtiyacı olmasından ziyade insanların hakkı olduğu için yapılmaktadır. Bu hak veya husus aynı zamanda insan haklarının da temelini oluşturmaktadır. Sosyal hizmet uygulamalarıyla kişilerin onuru ve değerine saygı duyulmaktadır. Bu uygulamayla insanların kendi ayakları üzerinde durabilmeleri ve toplum içinde işlevsellik kazanabilmeleri neticesinde sosyal adalet sağlanabilmektedir. Kuçuradi’ye (2017) göre meslek etiği, belirli bir meslek uygulanırken kişinin ne yapması gerektiği ya da ne yapmaması gerektiği yönünde yol göstermektedir(Kuçuradi, 2017). Meslek etiğinin en önemli özelliği, Dünyanın her yerinde aynı meslek adı altında çalışan meslek elemanlarının ortak davranmalarını gerekli kılmaktır. Bu özellik sosyal hizmet mesleği bünyesinde meslek etiği kavramına evrensel bir nitelik kazandırmaktadır (Aykara, 2016: 153-166).

Kuçuradi (2017), sosyal hizmet uzmanı mesleğini insan hakları ile ilişkilendirmektedir. Kuçuradi’ye göre insan hakları doğal olarak bu meslekle sıkı bir ilişki halindedir. Bu anlamda sosyal hizmet uzmanı mesleği, etik ilkeler örneğidir. Sosyal hizmet uzmanının temel amacı, insan haklarını korumaktır. Sosyal hizmet uzmanı, mesleği gereği insan hakları korunamayan kişilere yönelik bu hakları korumaya çalışmaktadır (Kuçuradi, 2017).

Reçber' in değerlendirmesine göre (2018) “Insanın sosyal bir varlık olmasl onu kendi türündeki diğer insanlarla iletişim ve ilişki kurma ihtiyacına itmektedir. Bu düşünce doğrultusunda sosyal hizmet, insanlar arası etkileşimi, ilişkinin kalitesini ve etkinliğini geliştirmek gayesiyle insanların sosyal işlevselliğini artırmaya çalışmaktadır. Sheafor vd. (2002), sosyal hizmet alanında bireylerin sosyal işlevselliğini artırmanın üç yolundan söz etmektedir. Bunlardan ilki, psikolojik ve temel ihtiyaçlara gereksinimi olanlara yönelik bu ihtiyaçları sağlamak için tasarlanan etkinlik ve çabaları içeren sosyal bakım, ikincisi kişinin ve ailenin işlevsiz, problemli veya sıkıntıll düşünce, duygu, davranış ve alışkanlıklarını değiştirmek veya düzeltmek için tasarlanmış eylemler bütünü olan sosyal tedavi ve üçüncüsü kişinin tespit edilen bir soruna sahip olmadan önce önleyici tedbirlere yönelik uygulamaları geliştirme ve sosyal güçlendirme olmaktadır. Eşitlikçi ve daha özgür ilişkilerin hâkim olduğu să̆llklı toplumların kurulması için insan haklart ilkelerinin, sosyal adaletin ve sosyal hizmetin hak temelli olarak tüm kişilere uygulanması gerekmektedir. Kişilerin insan olmaktan dolayı doğuştan getirdiği kapasite ve potansiyellerinin gelişimine sosyal hizmet katkıda bulunmaktadır. Sosyal hizmetin bu katkısı sosyal adaletin tesisi ve etkin olarak uygulanmaslyla anlaml hale gelmektedir. Sosyal hizmetin 
mevzuattan (anayasa, kanun vb.) kaynaklanan bir hak olması, kişilerin haklarını korumayı sağlamakta ve sosyal adaletin sürdürülebilmesi için de gerekli olmaktadır” (Reçber, 2018: 71-76).

Sosyal hizmet mesleğinin giderek önemli hale gelmesinde gerek ulusal gerek uluslararası toplumlar açısından bu meslek alanına giren sorunların artması etkili olmuş veya olmaktadır. Bunlardan birisi de çeşitli nedenlerle bulundukları yerleri terk etmek zorundan kalan insanların maruz kaldıkları durumdur. Dünyanın birçok bölgesinde çeşitli nedenlerle yerlerinden olan insanlar, daha huzur bulacakları yerlere göç etmeye başlamışlardır. $\mathrm{Bu}$ durum kimi kez zorunluluktan kaynaklanabilmektedir. İnsanların yıllardır yerleşik bulundukları yerlerde ortaya çıkan silahlı çatışma durumu, bu insanları can güvenliğini sağlamak amacıyla farklı yerlere göç etmelerine sebep olabilmektedir.

Zorunluluk nedeniyle göç etmek durumunda kalan kişiler, sığınmacı konumuna gelebilirler. Sığınmacı durumuna düşenlerin güvenliklerinin yanı sıra sosyal durumlarının da dikkate alınması gerekmektedir. Bu durum aslında sığınmacı konumundaki kişilerin temel hakları ve özgürlükleriyle de ilişkilidir. Göç olgusunun insani boyutunun ihmal edilmeden gündeme getirilmesi ile sığınmacıların toplumsal rollerinin, uyum sürecinin, eğitiminin, sağlık ve iş yaşamının düzenlenmesi açısından birçok disiplinin bir arada çalışması ön plana çıkmaktadır. Bu konuda gerek kamu gerek özel kurum ve kuruluşların bir koordinasyon ağı içinde çalışması kaçınılmaz hale gelmektedir (Buz, 2008: 120-130).

İnsanların zorunluluktan farklı yerlere göç etmelerinin çeşitli sebepleri bulunmaktadır. Bunlardan en önemlisi insanların yaşadıkları bölgelerde silahlı çatışmaların yaşanması durumudur. Elbette göç olgusunu sadece silahlı çatışmaya bağlamak eksik olacaktır. İnsanlar yaşadıkları yerlerde maruz kaldıkları ayrımcılık da (Guélamine ve Eberhard, 2011: 56-65) (ırk, dil, din vb. nedenlerle) zorunlu bir neden olarak yer değişikliğine sebep olabilmektedir. Hatta insanların bulundukları bölgedeki ekonomik vb. sorunlar nedeniyle de yerlerinden memnun kalmayarak başka yerlere gitme arayışında olduklarını belirtmek gerekir. Bu kişilerin yer değişikliğindeki en önemli tercih, sorun yaşamayacağı, temel haklarının ve özgürlüklerinin güvence altına alınacağı gelişmiş toplumların bulundukları yerler olmaktadır. Böyle bir durumda, yerlerinden olan insanlar kendilerinin yaptığı değerlendirme doğrultusunda gelişmiş toplumlara sahip ülkelere yönelmektedirler. Bu durum da sığınma olgusu doğrultusunda yönelinilen devletin tutumuyla doğrudan ilintili olmaktadır. Sığınma hakkı kapsamında yönelinilen devletin ülkesine giriş yapan kişilerin mevcut bir takım sorunlarının çözümünde sosyal hizmet mesleği, dolayısıyla bu hizmeti icra eden sosyal hizmet uzmanı devreye girmektedir. Ancak, bu çalışmada çalışmanın ana konusunu Fransa'daki uygulamanın oluşturması nedeniyle sadece sosyal hizmet uzmanı (assistant sociale) değil, aynı zamanda sığınmacılarla çalışan sosyal ihtiyaçlar doğrultusunda faaliyette bulunan diğer meslek elemanları da (sosyal hizmet uzmanı, psikolog, öğretmen, hukukçu vb.) şemsiye kavram olan "sosyal çalışmacılar" (travailleurs sociaux) kategorisi içerisinde değerlendirmeye alınmıştır. Bu uygulamanın Fransa açısından mevcut olduğunu ve yıllardır 
uygulandığını da özellikle belirtmek gerekir. Bu anlamda çalışmayı örneklemek gayesiyle Fransa' daki uygulamayı aktarmayı ve bu konuda değerlendirmeler yapmayı uygun gördük.

Çalışmada sosyal çalışmacıların sığınmacılarla çalışırken uymak zorunda oldukları etik kurallarıı veya duruma ilişkin yaşadığı veya yaşayabileceği hususları tespit etmeye çalıştık. Ayrıca çalışma yapılırken konunun hukuki boyutunu oluşturan sığınmacı, mülteci vb. kavramların açıklanmasına giremedik. Bu hususlar özellikle uluslararası kamu hukuku alanına girmektedir. Bir yandan maddi hata yapmamak diğer yandan uzmanlık alanımızın sınırı içerisinde kalmak amacıyla bahsi geçen kavramlara yönelik açıklama veya değerlendirme yapmayı uygun görmedik. Bu nedenle konuya ilişkin uzmanlık alanımızın kapsamında sadece sosyal çalışmacıların eylemleri ve/veya işlemleri değerlendirmeye alınmıştır.

\section{KAVRAMSAL ÇERÇEVE}

Çalışmada kullandığımız kavramlara ilişkin bu kısımda açıklama yapmak uygun olacaktır. Türkiye'de kimi durumlarda "sosyal hizmet uzmanı" ve "sosyal çalışmacı" isimlendirmeleri aynı anlamda kullanılabilmektedir. Bu tür bir kullanımın veya uygulamanın doğru olduğu iddia edilebilir. Hatta bu kavramlardan hangisi doğrudur şeklindeki soruya da kapsamlı olarak cevap aranabilir. Bu tür bir tartışma veya değerlendirme ayrı bir çalışmanın konusunu oluşturmaktadır. Konuyu dağıtmamak gayesiyle bu tür bir tartışmaya girmemeyi ve konumuz kapsamında kalmayı tercih etmekteyiz.

Fransa'daki kullanımı veya uygulamayı dikkate aldığımızda, sosyal çalışmacı ile sosyal hizmet uzmanının aynı anlamda kullanılmaması gerektiği görüşü ortaya çıkmaktadır. Bu anlamda, bu iki isimlendirmenin birbirinden farklı olduğu görüşünü savunmaktayız. Hatta çalışmanın başlığı dikkate alındığında başlıkta "sosyal çalışmacılar" tümcesi veya kavramını kullanmayı tercih ettik.

Fransa açısından "sosyal çalışmacılar" (travailleurs sociaux) toplum ile ilgili çalışma yürüten çeşitli meslek gruplarında yer alan kişileri kapsayan genel bir isimlendirme olmaktadır (Imbert, 2010: 128-136). Fransa'da İstatistik, Değerlendirme, Eğitim ve Araştırma Müdürlüğü 2000 yılının Aralık ayında yayımladığı çalışmasında sosyal çalışmacıları şu şekilde tanımlamaktadır: "săğlk, yaş, engellilik, aile veya sosyal durumları nedeniyle yardıma ihtiyacı olan ve zorluklarla karşılaşılan kişilerin yanında günlük olarak var olan kişiler"dir (Imbert, 2010: 129). Yine Fabienne Imbert'in tanımıyla sosyal çalışmacılar, kamu veya özel sektördeki yapılarda güçlük halinde bulunan kişilerin veya grupların desteklenmesinde ve yönlendirilmesinde, yasa tarafından öngörülen ve/veya izin verilen

\footnotetext{
1 Çalışmada sosyal çalışmacıların ve bu anlamda özellikle sosyal hizmet uzmanlarının uyması gereken etik kuralların neler olduğu, bu alanda çalışma yapan kişiler tarafından genellikle bilinmektedir. Aslında bu ilkelerin devletlere göre küçük çaplı farklılıklar dışında büyük oranda benzer olduklarını söyleyebiliriz (saygı, gizlilik, bilgiye ulaşma, ilgili kurumlara yönlendirme, temel haklara ve özgürlüklere saygı vb.). Bahsi geçen ilkelerin burada aktarılması çalışmayı betimleyici hale getireceğinden bu ilkelere ilişkin Fransızca ve Türkçe şu kaynaklara bakılması gerekmektedir: Code de déontologie des professions d'assistant d'hygiène sociale et d'assistant social, 2019; Sosyal Hizmet Mesleğinin Etik İlkeleri ve Sorumluluklar, 2019.
} 
bir görevin yerine getirilmesi kapsamında sosyal aktiviteleri yürütmeye yetkili ve nitelikli personelin bütünü olmaktadır (Imbert, 2010: 129-130).

Fransa açısından sosyal çalışmacıların tarihi gelişimlerini, kimlerden oluştuğunu ve bunların hangi meslek gruplarından (sosyal hizmet uzmanı, psikolog, eğiticiler(eğitimciler, hukukçular vb.) meydana geldiğini Jacques Ion ve Jean-Paul Tricart birlikte yazdıkları "Une entité professionnelle problématique: les travailleurs sociaux" isimli makalede detaylı olarak ele almışlardır. Jacques Ion ve Jean-Paul Tricart, sosyal çalışmacıları sadece bir kategorinin içerisine koymanın çok doğru olmayacağını belirtmişlerdir. Fakat Jacques Ion ve Jean-Paul Tricart, sosyal çalışmacılar grubunun en azından sosyal hizmet uzmanları, uzman/özel eğitimciler, yeni gelişen alanlar açısından tıbbi ve psikolojik yardımcılar, aile ve sosyal ekonomi danışmanları, sosyal yardımlara ilişkin vasiler, genç çocuk eğiti(m)ciler, uzman teknik eğitmenler, aile çalışanları vb. kişilerden oluştuklarını belirtmektedirler (Ion ve Tricart, 1985: 138).

Çalışmanın giriş kısmında belirttiğimiz gibi Fransa'da toplumsal mahiyetteki olgularla ilgili çalışmalar yapan sosyal çalışmacılar grubuna sosyal hizmet uzmanı, hukukçu, eğitmen, öğretmen, gönüllü vb. kişiler girmektedir. Bu anlamda Fransa'da sosyal çalışmacılar geniş meslek gruplarını kapsarken sosyal hizmet uzmanı veya uzmanlığı ise klasik nitelikte bildiğimiz meslek alanı olmaktadır. Konu kapsamında sosyal çalışmacıların sığınmacılara yönelik gerçekleştirdikleri çalışmalarla ilgili tarihi ve teorik bilgileri kısaca aktarmak uygun olacaktır.

\section{TARIHİ VE TEORİK ÖĞELER ITIIBARIYLA FRANSA'DA SIĞINMAYA İLIŞKİN ÇALIŞMALAR VEYA GELIŞMELER}

1970’li yıllara kadar Fransa'da sığınmacılara ilişkin yardım veya destek hizmeti çeşitli kurumlar tarafından dağınık olarak verilmiştir. Bu anlamda 1970'li yılların başlangıcı bir dönüşümü ortaya çıkarmıştır. Çünkü çeşitli yardım derneklerinin içinden sığınmacılara yönelik özel hareket birimleri ortaya çıkmaya veya gelişmeye başlamıştır. Bu dernekler, bu eylemlerini kamu hizmetine katılım olarak değerlendirmeye almışlardır. 1971 yılında kurulan Fransa Sığınma Ülkesi Derneği (Association France Terre d'Asile, 2019), 1975 yılında Ulusal Kabul Merkezi (Dispositif National d'Accueil, 2019) ismini alarak Fransa'da sığınma talebinde bulunanların uygun yerlere yerleştirilmesi hususunda çalışmalar yürütmeye başlamıştır (Garcia, 2018: 4). Fransa'daki dernekler zaman içerisinde sığınmacı alanında çeşitli yönlerden (sosyal, hukuki vb.) bir uzmanlık birimine dönüşmüşlerdir. Bahsi geçen dernekler, devletin alt birimi muamelesi görerek bir sosyal eylem sektörüne dönüşmeye başlamışlardır. Böyle bir uygulama özellikle 1980-1990 yılları arasında yaygın hale gelmiştir. Dernekler, bu amaç doğrultusunda kaynaklarının önemli bir kısmını kamu yararına sayılabilecek şekilde sı̆̆ınmacıların yerleşim masraflarını karşılamak üzere kullanmışlardır (D’Halluin-Mabillot, 2012: 92). Bu anlamda yardım sektöründe çok sayıda birim veya kuruluş oluşmaya başlamıştır. Dernekler, özellikle sığınma isteyenleri ve genel anlamda göç edenleri (pasaport, kimlik vb. belgeleri olmayanlar dâhil) savunmak amacıyla 
işbölümünde bulunmuşlardır. Sığınma talebinde bulunmayan göçmenler (yasa dışı yolla gelenler ve/veya yasal yolla gelip yasa dışı duruma düşenler) genel insan hakları ve temel özgürlükleri kapsamında değerlendirilmişlerdir. Ancak sığınma talebinde bulunanlar ise bir yandan temel haklar ve özgürlükler çerçevesinde değerlendirmeye alınırken diğer yandan da özellikle devletin egemenlik olgusuna istisna oluşturan 1951 tarihli Mültecilerin Hukuki Statüsü’ne İlişkin Cenevre Sözleşmesi’nin ilgili düzenlemeleri kapsamında dikkate alınmışlardır. Yukarıda da belirttiğimiz gibi bu Sözleşmenin ilgili düzenlemelerini yorumlamak veya değerlendirmek uzmanlık alanımızın dışında kalmaktadır.

Yukarıda bahsettiğimiz dernekler, parlamenterlerin ve hükümetin nezdinde yararlanıcı haklarının etkin kılınması yoğun çalışma yapmaktadırlar. Bununla birlikte, konu kapsamında Fransa Devleti'nin uyguladığı veya izlediği politikaları aşırı derecede eleştiren dernekler, iyi yönetim ve daha sınırlı istemlerde bulunan diğer derneklere göre kamu güçleriyle olan karşılaşmalarında giderek marjinal hale gelmektedirler (Garcia, 2012: 4).

\section{UYGULAMAYA İLIŞKİN DÜZENLEMELER (TEMSIL VE GÖRÜŞMELER)}

Sığınma taleplerinin kabulünün kurumsallaşması, talepleri kabul etmekle yükümlü kişiler üzerinde de etkileri veya sonuçları olmuştur. Gerçekten de yukarıda bahsettiğimiz dernekler, başlangıçta kamu otoriteleri tarafından gönüllülerden ve aktivistlerden oluşan yapılar olarak değerlendirilmiştir. Dernekler, sığınmacıların kabulünde zamanla profesyonelleşmeye başlamıştır. 1991 yılından itibaren Fransa'da sığınmacıların iş piyasasına girişleri yasaklanmıştır. Bu önlemin sonucunda konaklama merkezlerinde kabul yerleri artmış ve gönüllü derneklere veya yapılanmalara finansman desteği sağlanarak personel sayılarını artırma imkânı verilmiştir. Bahsi geçen bu dernekler zamanla, personellerinin ücreti ve istihdamı konusunda devletten bağımsız olmaya başlamışlardır (Garcia, 2012: $4)$.

1990’lı yıllarda bu dernekler, lokal olmaya ve çeşitleri artmaya başlamıştır. Ancak piyasa veya ortam, Sonacotra, Fransa Sığınma Ülkesi Derneği ve Mülteci Forumu gibi bölgesel veya ulusal yapılanmalar etrafında toplanmış veya yoğunlaşmıştır. O dönemde Fransa Sığınma Ülkesi Derneği Başkan1 Jérôme Valluy, “ben gönüllüler problemini çözdüm: benim derneğimde ücretli kategorisinde olmayan hiçbir gönüllü bulunmamaktadır" şeklinde açıklama yaparak bu tür yapılanmalarda sığınmacılara yönelik kontrolün daha kolay sağlanabileceğini belirtmiştir (Valluy, 2007, s. 20). Son y1llarda bu derneklerde veya yapilanmalarda istihdam edilen personelin (aile ve sosyal ekonomi danışmanları, sosyal hizmet uzmanları, hukukçular ve diğer alanlardaki genç diplomalılar vb.) uzmanlardan oluşmasına özen gösterilmektedir (D’Halluin-Mabillot, 2012: 94; Garcia, 2018: 5).

$\mathrm{Bu}$ derneklerin içinde personel sayısının artmasıyla birlikte, sığınmacılara yönelik gözlem yapma imkânı da artmaktadır. Ancak belirtmek gerekir ki sosyal çalışmacıların hareket alanı çok da geniş olmamaktadır. Çünkü sosyal çalışmacıların sığınmacılara ilişkin elde ettikleri kişisel verilerin Fransa'daki valilik makamları tarafından girilebilir veya görülebilir olmaları, konaklamaya ilişkin 
bilgilerin merkezileşmesi ve kişilerin takibinin giderek artan oranda zorlaşması gibi nedenler, sosyal çalışmacıların hareket alanını sınırlayabilmektedir. Diğer bir ifadeyle sığınmacılarla çalışan sosyal çalışmacılar, sıkı kontrol edilen bir ortamda hareket etmek durumundadırlar (Garcia, 2018: 5).

2000'li yılların ortasında sığınma talepleri için konaklama merkezlerinin artmasıyla birlikte, şu üç olguya da cevap verilmesi önemli olmuştur. Bunlardan birincisi harcamaların iyi kontrol edilmesi, ikincisi konaklama merkezlerine giriş yapma prosedürünün basitleştirilmesi ve üçüncüsü ise prosedürden kaynaklı sığınma istemlerinin reddedilmesiyle geri dönüş (sınır dışı etme) koşullarının iyileştirilmesi (hatta bunun korunması) olmaktadır (Garcia, 2018, s. 5). Konaklama veya kabul merkezlerinde çalışan kişilerin (sosyal çalışmacıların) eşlik etme ve kontrol eylemleri, göç edenlerin ve sığınma isteyenlerin temel hakları ve özgürlükleri doğrultusunda olması gerekmektedir. Bu merkezlerde çalışanlar sığınma dosyaları oluşturmakta, haklara ulaşım sağlamakta ve çıkışların yönetimi ve sorumluluğu kapsamında gerekli bilgilendirmeler de yapmaktadırlar (Bouquet, Madoui ve Nivolle, 2011: 6-9; Kobelinsky, 2008: 125).

Sığınmacılarla çalışan sosyal çalışmacıların karşı karşıya bulundukları çelişkileri de burada belirtmek gerekir. Sosyal çalışmacılar, mesleki etik ilkelerine ters olan işleri kabul ederek bu alanda işlerini kamu otoriteleri nezdinde sürdürdüklerini vurgulamaktadırlar (Hughes, 1996: 81). Bunun için sosyal çalışmacılar öncelikle "pratik çözümler" olarak adlandıracağımız uygulamalar yapmaktadırlar. Diğer bir ifadeyle sosyal çalışmacılar, belirli bir çerçevede halka yönelik özel sosyal politikaların belirlenmesine ve bunu yasal zemine dayandırılmasına çalışmaktadırlar. Böylece bu husus, onlara kendi özel görevlerinin yasal çerçeveye oturmasına olanak sağlamaktadır. Bu anlamda görevini yerine getiren sosyal çalışmacılar, gerçek sığınmacıları, sahte sığınmacılardan hatta ekonomik gerekçelerle göç eden kişilerden ayırt etmekte zorlandıklarını belirtmektedirler (Garcia, 2018: 6).

Birçok devlette olduğu gibi Fransa' da da özellikle 24.07.2006 tarihli ve "Sarkozy Kanunu" olarak da isimlendirilen yasal düzenlemede "seçilmiş göçmen" ve "maruz kalınan göçmen" olgularına rastlanabilmektedir (Loi n ${ }^{\circ}$ 2006-911 du 24 juillet 2006 relative à l'immigration et à l'intégration, 2019). Aslında bu durum sosyal çalışmacıların etik durumu ile pek de bağdaşmamaktadır. Çünkü sığınma talebinde bulunan ve kalifiye eleman olarak nitelendirdiğimiz kişilerin istemleri kabul edilmekte ve bu kategoride olmayanlarınki ise reddedilmektedir. Bu durum gerçekten de sığınma talebi haklı nedenlere dayanan ancak kalifiye olmayan kişiler açısından negatif yönde bir gelişme olarak değerlendirilmektedir. Sığınma talebinde bulunanların taleplerinin temel haklar ve özgürlükler kapsamında değil de sadece yararlı ve yararlı olmayan kişiler şeklinde yapılması, sosyal çalışmacıları oldukça güç duruma düşürmektedir. Oysa sığınma talebiyle gelen kişi yabancı uyruklu da olsa yasal düzenlemeler açısından insan olmaktan dolayı eşit muameleye tâbi tutulma ve bu şekilde değerlendirmeye alınma hakkına sahiptir (Garcia, 2018: 6). 
Özel mahiyette sığınma alanında ne yazık ki sınıflandırma (Lochak, 2006: 4-8) durumunun da ortaya çıktığını belirtmek gerekir. Kobelensky, sığınma politikası yoluyla ilgili kamuoyunu karakterize etmek için terminolojinin nasıl geliştiğini şu şekilde açılamaktadır: "otuz yıl önce, slğınma talebinden değil sadece mültecilerden bahsediyorduk. 1980'li yıllar boyunca, sı̆ğnma talebi mükemmel bir şekilde idari kategoriye dönüştü. 1980'li yılların sonunda, kamuoyunda "sahte mülteci" kategorisi ile ilk etapta "sahtecilik" mantı̆̆ yerleşmeye başlamıştır. On yıl sonra, sadece "sahte mülteci”" sorunu değil aynı zamanda "sahte sı̆̆ınma istemcileri" belirgin hale gelmiştir" (Kobelinsky, 2008: 115). Ĕger gerçek sığınma talebinde bulunan ile gerçek mülteci gerekli dikkati ve saygınlığı hak ediyorlarsa, bunların sahte olanların durumuna oranla hızlı bir şekilde kurumsal düzenlemelere tâbi olarak durumlarının açıklığa kavuşturulması ve statülerinin belirlenmesi önemli olmaktadır. Mesleki anlamda, kendi eylemlerini haklı çıkarma amacı kapsamında, bu kategoride olanlar nihayetinde sosyal çalışmacılar tarafından tespit edilebilmektedir.

Sophie Garcia gerçekleştirdiği çalışmasında sosyal çalışmacılar kategorisinde çalışan FransızcaÇince tercümanlığı yapan kişinin, sığınmacı kabul merkezinde çalışırken Çinli hayat kadınlarının sahte sığınma taleplerinde bulunduğunu belirtmiştir (Garcia, 2018: 6). Aslında benzer durumun bu tür merkezlerde faaliyet gösteren diğer sosyal çalışmacılar için de geçerli olduğu söylenebilir. Bu anlamda sosyal çalışmacılar gerek mesleki tecrübeleri gerek çeşitli hususlarla gerçek ve/veya sahte sığınma başvurularını ilk aşamada tespit etmeye çalışmaktadırlar. Sosyal çalışmacılar, yetkilerinin verdiği statü ile sığınma istemi dosyalarını sığınma taleplerinin gerçek olup olması açısından incelemekte, talepte bulunanların geldikleri ülkede maruz kaldıkları eylemlerin ve/veya işlemlerin sığınma talebi için yeterli olup olmadığına bakmaktadırlar. Sosyal çalışmacılar, görevlerini yürütürken tesis ettikleri kararların yasallığını ve meşruiyetini bilmek durumundadırlar. Diğer bir ifadeyle sosyal çalıșmacılar, eylemlerini ve/veya işlemlerini yasal dayanak içerisinde yapmak zorundadırlar. Elbette bu yasal dayanak iç hukuktan kaynaklı düzenlemeler olmaktadır. Ancak, sığınma talebinde bulunan kişilerle sosyal çalışmacıların ilişkisi doğal olarak sosyal çalışmacıların bulundukları idari kadrolara bağlıdır. Sosyal çalışmacılar, görevleri ve yetkileri kapsamında sığınma talebinde bulunanlara yönelik mesai harcamaktadır. Sosyal çalışmacılar, özellikle sığınma talepleri dayanaktan yoksun olan kişilerin dosyalarını incelerlerken çok zor durumda kaldıklarını belirtmektedirler. Valluy'nin vurguladığı gibi başvuru dosyasının dayanaksız olması halinde, sığınma talebinde bulunanlar doğal olarak sığınma kabul merkezlerinden çıkarılmakta ve gerekli prosedürün işletilmesi kaydıyla geldikleri menşe ülkeye gönderilmeleri gerekmektedir (Valluy, 2007: 256).

Garcia, sığınma kabul merkezlerinde çalışan sosyal çalışmacıların alanlarında uzman olmalarının son derece önemli olduğunu vurgulamaktadır. Çünkü kimi kez tercümanlar, gazeteciler gibi sosyal hizmet misyonuna sahip olmayan kişilerin yanlış bilgiler, değerlendirmeler ve yönlendirmeleri sonucunda sığınma taleplerinin sağlıklı olarak gerçekleşemediğini vurgulamıştır. Garcia tarafından görüşü alınan sosyal hizmet uzmanı Élise, iş yüklerinin fazla olması nedeniyle sadece durumu acil 
olanlarla ilgilenebildiklerini, duurumu belirlenen mülteci statüsünde olan kişilerle fazla ilgilenemediklerini belirtmiş̧ir. Hatta uzman olmayan kişilerin iç mevzuatı (kanun, yönetmelik vb.) anlayarak bu mevzuatı uygulama ihtimali düşük olabilmektedir (Garcia, 2018: 8)2.

Sosyal çalışmacılar, gizliliği ön planda olan bir görev icra etmektedirler. Bu görevin icra edilmesinde mevzuatın dikkate alınması esastır. Mevzuat dikkate alınarak kendilerine sığınma hakkı verilen veya verilmeyen kişilerin yararlanabilecekleri haklar ve üstlenebilecekleri sorumluluklar açıklanmakta veya aktarılmaktadır (Spire, 2017: 93).

Fransa'da sosyal çalışmacılarının oluşturduğu yapıda görev üstlenen ve/veya yetki kullanan kişiler, sığınmacılara yardım etmeyi amaçlayarak bir şeye (işe) yaradıklarını ispatlamaya çalışmaktadırlar. Bunların içerisinde resmi mahiyette görev yapanların, profesyonel nitelikte görev üstlendiklerini hatırlatmak gerekir. Örneğin sistem içerisinde görev üstlenen ve/veya yetki kullanan sosyal hizmet uzmanları, bu hususu profesyonel bir iş veya meslek olarak benimsemiş durumdadırlar. $\mathrm{Bu}$ durum sosyal hizmet uzmanlarını meslekleri gereğince benimsedikleri etik ilkeler doğrultusunda eylemde bulunmaya ve/veya işlemler yapmaya zorlamaktadır. Aslında sosyal hizmet uzmanlarının evrensel mahiyette aldıkları eğitim de bu doğrultudadır.

Garcia, Élise ismindeki sosyal hizmet uzmanı ile yaptığı söyleşide, Élise’in Göçmenler İçin Acil Konaklama Merkezleri'nde görevli olduğunu, zaman zaman diğer birimlerde de görev üstlendiğini belirtmektedir. Élise, diğer birimlerde görev yaparken statüsü belirlenmiş mültecilerin ihtiyaçlarının karşılanması hususunda psikolojik olarak kendisini yararlı hissetmediğini, zira bu kategoride olan kişilere yönelik hizmetlerin standart ve belli olduğunu ve bu nedenle kendisini daha yararlı olabileceğini hissettiği Göçmenler İçin Acil Konaklama Merkezleri’ne dönüş yaptığını vurgulamıştır (Garcia, 2018: 9). Bu durum, sosyal hizmet uzmanının aldığı eğitimle de doğrudan ilintilidir. Nihayetinde sosyal hizmet uzmanı aldığı eğitim doğrultusunda çeşitli alanlarda insanlara yararlı olduğunu veya olabileceğini kabul ettiği ölçüde kendini mutlu hissetmekte ve böylece daha yararlı olabilmektedir.

\section{SOSYAL ÇALIŞMACILARIN SIĞINMACILARA İLIŞKİN ÇALIŞMALARINDA BAZI ETİK KURALLARA AYKIRI EYLEMLERİ VE İŞLEMLERİ}

Fransa'da sosyal hizmeti doğrudan ilgilendiren 2002-2 sayılı ve 02.01.2002 tarihli Mediko Sosyali ve Sosyal Eylemi Yenileyen Kanunun (Ispenian, 2005: 49-62; Loi $\mathrm{n}^{\circ}$ 2002-2 du 2 janvier 2002 rénovant l'action sociale et médico-sociale, 2019) ilgili düzenlemelerini burada hatırlatmak gerekir. Bu kanun bir yandan kamu otoritelerinin yetkilerini, diğer yandan da yararlanıcıların haklarını ve sorumluluklarını düzenlemektedir. Doğal olarak sosyal hizmet uzmanları, bu kanun düzenlemeleri kapsamında hareket etmek zorundadırlar. Özellikle bahsi geçen Kanunun 84. maddesi sığınmacıların

2 Şahin Taşğın, benzer durumun veya uygulamanın Türkiye'de de olduğunu vurgulamaktadır. Şahin Taşğın, konuya ilişkin haklı mahiyette “...sosyal hizmet eğitimi almamış meslek mensuplarının sosyal hizmetler alanında istihdam edilmeleri, yönetici konumunda olmaları ve ayrıca da sosyal hizmetler alanında çalı̧̧an mesleklerin aynı işleri yapar hale getirilmeleri gibi sorunlar, süpervizyon ihtiyacını acil hale getirmektedir" şeklinde bir görüş savunmaktadır (Şahin-Taşğın, 2019: 1028-1029). 
istemlerinin kabul edilmesi halinde, sosyal yardım sisteminin içerisine nasıl dâhil olabileceklerini düzenlemektedir.

Her devletin sisteminde olduğu gibi Fransa'da da bürokrasiden ve mevzuatın gereklerini yerine getirmeden kaynaklı zorluklar yaşanmaktadır. Bu anlamda, sosyal çalışmacılar grubunda yer alan ve özellikle gönüllülük esasına dayalı olarak çalışma yürütenler, bu durumdan rahatsız olduklarını belirtmektedirler. Ancak, sığınma talebi olan kişiler de dâhil olma üzere sosyal ihtiyaçların devlet otoriteleri tarafından karşılanmasında geçerli mevzuatın uygulanma zorunluluğu bulunmaktadır. Kamu otoritelerinin mevzuatı zorlayan veya temel hakların ihlali niteliğinde olabilecek istemlere karşı sosyal çalışmacıların direnç göstermeleri de beraberinde çeşitli problemleri getirebilmektedir. Bu konuda Garcia, Göçmenler İçin Acil Konaklama Merkezleri'nde sosyal hizmet uzmanı olarak görevli Mathilde ile yaptığı söyleşide, Mathilde'in kendilerinin benimsemediği veya insan haklarının ihlal edildiği bir durum karşısında itirazlarının olması halinde, sahip oldukları statüyü kaybetme risklerinin olduğunu belirtmiştir (Garcia, 2018: 11).

Sosyal çalışmacılar, kamu otoritelerinin (özellikle valilik bünyesindeki makamların), konaklama merkezlerinde bulunan yabancı kişilere ilişkin kişisel nitelikte ve gizliliği ön planda olan bilgilerin kendilerine verilmesi hususunda baskı yaptıklarını belirtmişlerdir. Bu konuda Garcia, söyleşide bulunduğu sosyal hizmet uzmanı Élise'in mevcut statüsünü kaybetme tehlikesini göze alarak üst makamlara karşı direndiğini ve sonuçta bu bilgilerin transferini gerçekleştirmediğini vurgulamıştır (Garcia, 2018: 11).

Sığınma talebinde bulunanların önemli bir kısmı, sığınma taleplerinin kabul edilmesini ve kendilerine ikamet izinlerinin verilmesini istemektedir. Sığınma talebinde bulunanların ileriye dönük kişisel projeleri (statü, iş vb.) ilk aşamada öncelikli sırada bulunmamaktadır. Burada sosyal çalışmacılarının kişisel mahiyetteki projeleri de gerek mevzuattan gerek üst otoritelerin baskısından gerçekleşememe ihtimali bulunmaktadır. Sosyal çalışmacılar hiyerarşi, bürokrasi, kaynak yetersizliği gibi nedenlerle sığınma merkezlerinde zorluklarla da karşılaşmaktadırlar (Garcia, 2018: 12).

Yukarıda belirttiğimiz gibi, sığınma merkezlerinde görev üstlenen sosyal çalışmacıların karşılaştıkları en önemli problem, görüşme yapılan kişilere ilişkin gizli kalması gereken bilgilerin valilik makamları tarafından istenmesidir. Bu konuda sosyal hizmet uzmanı Élise, işini kaybetmeyi bile göze alarak bu bilgileri verme hususunda direnç gösterdiğini belirtmiştir.

Garcia, yapmış olduğu söyleşide yukarıda kendisinden bahsettiğimiz sosyal hizmet uzmanı Mathild'in çalıştı̆̆ yerde kendi şefinin mesleki etik kurallarına uyması hususunda sorun çıkarmadığını, fakat hangi bilgilerin kamu otoritelerine iletilmesi gerektiği hususunda engel çıkardığını belirtmiştir. Sosyal çalışmacılar, yerleşmeleri sağlanılan kişilerin sığınma taleplerinde kullanılması amacıyla bazı bilgilere ihtiyaçları bulunmaktadır. Bu bilgilerin de kamu otoritelerinde olması nedeniyle sosyal 
çalışmacılar bu kamu otoriteleriyle her zaman zorunlu bir ilişki kurmak durumunda kalmaktadırlar (Garcia, 2018: 13).

Sosyal çalışmacıların önemli bir kısmı, sığınma başvuruları reddedilen kişilerin konaklama merkezlerinden çıkarılmalarını ve sınırdışı edilmelerini engellemek için mevzuatın izin verdiği ölçüde her türlü aracı kullanmaya çalışmaktadırlar. Bu anlamda sosyal çalışmacılar, sığınma başvurusunda bulunanları ziyarete gelen kişilerin (arkadaşı, yakını vb.) bu konaklama merkezlerinde gece kaldıklarını ve kendilerinin de buna göz yumduklarını belirtilmektedirler (Garcia, 2018: 14). Burada sorgulanması gereken husus şudur: acaba kurallara uymayan kişilerin salt sokakta kalacakları endişesiyle konaklama merkezlerinde tutulmalarının sağlanması doğru mudur? Aslında, sığınma başvuruları reddedilenlere veya konaklama merkezlerinde kalma hakkı olmamasına rağmen burada kalmaya devam edenlere yönelik başka mekanizmaların devreye sokulması gerekmektedir. Burada sosyal çalışmacılar, kişilere yönelik temel hakları ve özgürlükleri dikkate almakta ve mevcut etik kuralları ise bir kenara bırakmaktadır. Oysa uygulanan kural kişiyi korunaksız bıraktığı iddia edilse bile, bu korunaksız durumu düzenleyen başka bir kural bulunmaktadır veya bulunmalıdır. Fransa, iç hukukuna göre sığınma talebi reddedilen kişiyi veya kişileri uluslararası mülteci hukukuna da uygun olmak kaydıyla ya sınır dışı etmekte ya da içeride tutma durumunda kalmaktadır.

Konu kapsamında yukarıda ismini verdiğimiz sosyal hizmet uzmanı Mathilde ile gerçekleştirilen söyleşide, Mathilde çalıştığı konaklama merkezine, sığınma başvuruları reddedilen (personnes déboutées) kişilerin idari konularda soru sormak gayesiyle geldiklerini, hakları olmamasına rağmen bunların sorularına cevap bulmak için kendilerinin kabul edildiklerini belirtmektedir. Bu kişiler, çeşitli nedenlerle konaklama merkezlerini terk etseler bile statüleri ne olursa olsun kendilerine informel düzeyde yaradım yapılmaktadır. Örneğin, sosyal çalışmacılar konaklama merkezinden ayrılan kişilerin tutulduğu gözaltı merkezlerinde kalan kişilere zorunlulukları bulunmamasına rağmen avukat bulmakta ve avukatlık ücretini de gönüllülerin oluşturduğu Paris d'Exil (Paris Sürgün Derneği) derneğine ödettirmektedirler. Hatta sosyal hizmet uzmanı Mathilde, görev çerçevesinde olmamasına rağmen konaklama merkezinden ayrılan kişiye destek olmak gayesiyle duruşmasına gittiğini ve bundan da amirinin haberinin olduğunu, ancak amirinin kendisine neden duruşmaya gittiğini sormadığını belirtmiştir (Garcia, 2018: 14-15).

Konaklama merkezlerinde çalışan sosyal çalışmacılar, görevlerini yerine getirmede ve yetkilerini kullanmada yasal mevzuatı dikkate almak zorundadırlar. Ancak, sosyal çalışmacılar kimi kez mevzuatın dışına çıktıklarını vurgulamışlardır. Bunlardan sosyal hizmet uzmanı Élise, kendisinin insanların olduğu bir serviste çalıştı̆̆ını, bu servisin bir işverene veya devlete ait olduğunu düşünmeksizin görev yürüttüğünü ve bulunduğu serviste sınır dışı edileceğini anlayan başvurucunun kendisini hasta olduğunu söylediğini, ancak bu kişinin gerçekte hasta olmadığını bildiğini, fakat meslek etiğini bir kenara bırakarak başvurucuya insan hakları çerçevesinde hasta muamelesi yaptığını belirtmiştir (Garcia, 2018: $15)$. 
Sosyal çalışmacılar, sığınma talebinde bulunan kişilerle bire bir çalışmaları nedeniyle, gerek çalışanlar gerek başvuruda bulunanlar arasında yukarıda belirttiğimiz gibi informel ilişkiler de gelişebilmektedir. Çünkü sığınma başvurusunda bulunanlar ilk geldiklerinde Fransa'ya ilişkin, idari, hukuki, yargısal, ekonomik vb. konularda neredeyse hiçbir bilgiye sahip değildirler. Bu anlamda sosyal çalışmacıların bu kişilere olumlu veya olumsuz yöndeki yaklaşımları, bir nevi Fransa Devleti'nin yaklaşımı olarak da algılanabilmekte veya değerlendirilebilmektedir. Sosyal çalışmacılar, sığınma talebinde bulunan kişilerin ileriye dönük kişisel projelerinin neler olduğunu saptamakta, hatta daha öteye giderek Fransa'da sığınma başvurusu kabul edilen kişileri takip bile edebilmektedirler.

Sosyal çalışmacılar, sığınma başvurusunda bulunanları temel haklar ve özgürlükler kapsamında değerlendirerek kimi kez Fransa Devleti'nin belirlediği mevzuatı zorlayacak eylemlere de girişebilmektedirler. Aslında buradaki en önemli husus, anlık gelişen durumlara tamamıyla uymayan yasal düzenlemeler olmaktadır. Diğer bir ifadeyle sosyal ihtiyaçları karşılamak gayesiyle tesis edilen yasal düzenlemeler gelişen teknoloji, ani olarak meydana gelen yasal veya yasa dışı göç gibi hususlarda yetersiz kalabilmektedir. Hatta mevcut yasal düzenleme, kimi durumlarda uygulandığında sığınma başvurusunda bulunanların gerekli şartları sağlamaması gibi nedenlerle yetersizliği bile iddia edilebilmektedir. Ancak, yasaların yetersizliğini öne sürüp kuraldışı olarak nitelendirebileceğimiz bir eyleme girişmenin veya işlemi tesis etmenin de sosyal çalışmacıya yönelik sorumluluk doğuracağı açıktır. Bu durumda yasanın yetersizliği nedeniyle temel haklara ve özgürlüklere sığınarak direnç göstermek, sosyal çalışmacıyı sorumlu hale getirebilmektedir.

\section{SONUÇ}

Fransa'da sosyal çalışmacıların kapsadığı grup geniş niteliktedir. Sosyal hizmet uzmanı da bu grubun içerisinde yer almaktadır. Sosyal çalışmacılar, Fransa'da görevleri doğrultusunda yetki kullanırken ve sorumluluğa muhatap olurken Fransa Devleti'nin iç mevzuatı doğrultusunda hareket etmektedirler. Aslında bu mevzuat sosyal çalışmacıların hareket alanını da açıkça belirlemektedir. Sosyal çalışmacılar, mesleklerinin gereğini yerine getirirken aynı zamanda mesleğinin etik kurallarına da uymak zorundadırlar.

Dünyanın birçok bölgesinde çeşitli nedenlerle ulusal ve uluslararası düzeyde çatışmalar olmakta, hatta bu çatışmalar kimi kez savaş düzeyine bile varabilmektedir. Bu durumdan etkilenen kişiler veya gruplar gelişmiş ve yaşama güvencesinin yüksek olduğu bölgelere göç etmektedirler. Bu bölgelerden birisi de Fransa olmaktadır. Fransa'ya çeşitli nedenlerle sı̆̆ınma başvurusunda bulunan ve başvurularıyla ilgili işlemleri devam eden kişilere yönelik çalışma yürüten sosyal çalışmacılar, çalışmaları süresince yukarıda belirttiğimiz gibi özellikle kamu otoritelerinden gelen baskılar ve yasa dışı istemlere karşı direndiklerini belirtmektedirler. Sosyal çalışmacıların istihdam edildikleri kamu kurumlarında amir pozisyonunda bulunan kişilerin, sığınma talebinde bulunanlara ait kişisel, gizli vb. bilgileri istemeleri hususu, bu konuda verilebilecek en önemli örnektir. 
$\mathrm{Bu}$ çalışmada sadece sığınma başvurusunda bulunan kişilere yönelik çalışma yapan sosyal çalışmacıların etik kurallara aykırı durumlarla karşılaşmaları halinde gerçekleştirdikleri eylemler ve/veya tesis ettikleri işlemler değerlendirme konusu yapılmıştır. Çalışmanın amacı, konuya ilişkin Fransa'daki mevcut durumu tespit ederek ileriye dönük Türkiye açısından gerçekleştirilecek çalışmalarda iki devletin karşılaştırılabilmesine olanak sağlamaktır. Böyle olmakla birlikte çalışmanın bütünü değerlendirmeye alındığında sosyal çalışmacıların genel olarak bağlı kaldıkları etik kurallar evrensel özellikleri açısından benzer niteliktedir. Burada en önemli ilke, etik kurallara aykırı bir şekilde istemde bulunan kamu otoritelerinde görev yapan kişilere karş1 şikâyet, soruşturma vb. prosedürlerin etkin olarak işletilip işletilmediğidir. Eğer sosyal çalışmacı, etik duruma aykırı istemlere direnirken iç mevzuatın uygulama açısından kendisini koruyacağından emin ise bu istemlere karşı direnci daha da artmaktadır. Ancak tersi bir durumda sosyal çalışmacı kendisini güvencesiz hissetmekte ve etik dışı durumlara karşı direnci azalabilmektedir.

\section{KAYNAKÇA}

Aykara, A. (2016) "Sosyal Hizmet Etiğinde Evrenselcilik ve Kültürel Görecelik", Toplum ve Sosyal Hizmet, 27(2): 153-166.

Bouquet B., Madoui M., \& Nivolle, P. (2011) "Les travailleurs sociaux à l'épreuve de l'immigration", Hommes et migrations, 1290: 6-9.

Buz, S. (2008) “Türkiye Sığınma Sisteminin Sosyal Boyutu”, TBB Dergisi, 76: 120-130.

Code de déontologie des professions d'assistant d'hygiène sociale et d'assistant social, https://www.ifsw.org/wp-content/uploads/ifsw-cdn/assets/Luxembourg_code.pdf, (17.12.2019).

D’Halluin-Mabillot E. (2012). "Les épreuves de l'asile. Associations et réfugiés face aux politiques du soupçon", Paris: éd. EHESS.

Dispositif National d'Accueil, http://www.ofii.fr/demande-d-asile, (13.12.2019).

France terre d'asile, https://www.france-terre-asile.org/, (27.11.2019).

Garcia, S. (2018) "L'éthique des travailleurs sociaux face aux politiques de l'asile: entre "arrangements pratiques" et "pratiques de contournements", La politique de l'action sociale, 10: 1-19, http://www.sas-revue.org/images/pdf/N10d10/L-ethique-des-travailleurs-sociaux-face-auxpolitiques-de-l-asile.pdf, (22.12.2019).

Gökçearslan Çifçi, E. ve Gönen, E. (2011) “Sosyal Hizmet Uygulamalarında Etik Karar Verme Süreci”, Toplum ve Sosyal Hizmet, 22(2): 149-160.

Guélamine, F., \& Eberhard, M. (2011) "Former les travailleurs sociaux dans le domaine des discriminations", Hommes et migrations, 1290: 56-65. 
Kobelinsky, C. (2008) "Faire sortir les déboutés. Gestion, contrôle et expulsion dans les centres pour demandeurs d'asile en France", Cultures \& Conflits, 71: 113-130.

Kuçuradi, I. (2017) “Sosyal Hizmetlerde Etik Eğitimi”, Maltepe Üniversitesi, 23-27 Ocak, İstanbul.

Imbert, F. (2010) “Qui sont les travailleurs sociaux?”, Les Cahiers Dynamiques, 48: 128-136.

Ispenian, I. (2005) “La loi du 2 janvier 2002 ou la reconnaissance de droits aux usagers”, Gérontologie et société, 28(4): 49-62.

Ion, J., \& Tricart, J-P. (1985) "Une entité professionnelle problématique: les travailleurs sociaux", Sociologie du Travail, 27(2): 137-153.

Kobelinsky, C. (2008) "Faire sortir les déboutés. Gestion, contrôle et expulsion dans les centres pour demandeurs d'asile en France", Cultures \& Conflits, 71: 113-130.

Lochak, D. (2006) "Le tri des étrangers: un discours récurrent”, Plein droit, 69(2): 4-8.

Loi $\mathrm{n}^{\circ}$ 2006-911 du 24 juillet 2006 relative à l'immigration et à l'intégration, https://www.legifrance.gouv.fr/affichTexte.do?cidTexte=JORFTEXT000000266495, (15.12.2019).

Loi $\mathrm{n}^{\circ}$ 2002-2 du 2 janvier 2002 rénovant l'action sociale et médico-sociale, https://www.legifrance.gouv.fr/affichTexte.do?cidTexte=JORFTEXT000000215460\&categorie Lien=id.

Reamer, F.G. (1999) “Social Work Values And Ethics. Second Edition”, New York: Columbia Univesity Press.

Reçber, B. (2018) “İnsan Hakları ve Sosyal Adalet Açısından Devletin Çocuklara ve Kadınlara Yönelik Sunduğu Hizmetler: Aile ve Sosyal Politikalar Bakanlığı Çalışanları Örneği”, Doktora Tezi, Bursa Uludağ Üniversitesi, Sosyal Bilimler Enstitüsü, Bursa.

Spire, A. (2017) "Comment étudier la politique des guichets? Méthodes pour enquêter sur le pouvoir discrétionnaire des agents de l'immigration”, Migrations Société, 29(167): 91-100.

Sosyal Hizmet Mesleğinin Etik İlkeleri ve Sorumluluklar, http://shsempozyum2014.baskent.edu.tr/files/shuetiksorumlugu.pdf, (18.12.2019).

Şahin Taşğın, N. (2019) “Sosyal Hizmet Süpervizyonu ve Türkiye İçin Öneriler”, Toplum ve Sosyal Hizmet, 30(3): 1005-1032.

Valluy, J. (2009) Rejet des exilés. Le grand retournement du droit d'asile, Bellecombe-en-Bauges, La collection TERRA: éd. du Croquant. 